\title{
THE IMPACT OF SOCIAL MEDIA ON KNOWLEDGE CREATION, INNOVATION, AND PERFORMANCE IN SMALL AND MEDIUM ENTERPRISES
}

\author{
Merry Mita Moy ${ }^{*) 1}$, Eko Ruddy Cahyadi**), and Elisa Anggraeni***) \\ *) Faculty of Economic and Management, IPB University \\ Jl. Agatis, Campus IPB Dramaga Bogor 16680 \\ **) Departement of Management, Faculty of Economics and Management, IPB University \\ Jl. Agatis, Campus IPB Dramaga Bogor 16680 \\ ${ }^{* * *}$ Departement of Agroindustrial Technology, Faculty of Agricultural Technology, IPB University \\ Jl. Agatis, Campus IPB Dramaga Bogor 16680
}

\begin{abstract}
In the globalization era, social media is widely used by small and medium enterprises (SMEs) to promote and market their products. However, there is still a limited objective of this study the effectiveness of social media in improving the business performance of SMEs. This study analyzes the effect of social media on knowledge creation, innovation, and performance in SMEs in Jabodetabek (Indonesia). This study combines online and offline methods to collect data from a sample of 384 SMEs. Data was analyzed SEM-PLS. The variables are social media, knowledge creation, innovation, and performance. The result is that social media does not havea direct impact on performance. However, social media has a significant influence on business performance, moderating knowledge creation, and innovation. Effectiveness of social media on improving business will the partner use for knowledge creation and innovation.
\end{abstract}

Keywords: social media, knowledge creation, innovation, performance, SMEs

Abstrak: Di era globalisasi membuat media sosial banyak digunakan oleh para pelaku bisnis (UKM) untuk mempromosikan dan memasarkan produk melalui media sosial. Penelitian ini menganalisa dampak media sosial terhadap peningkatan kinerja UKM. Penelitian ini bertujuan menganalisis dampak media sosial pada penciptaan pengetahuan, inovasi dan kinerja pada UKM di Jabodetabek (Indonesia). Penelitian ini menggabungkan metode online dan offline untuk menggumpulkan data dari 384 responden pada UKM di Jabodetabek. Analisis data menggunakan SEM-PLS. Variabel dalam penelitian ini adalah media sosial, penciptaan pengetahuan, inovasi dan kinerja. Hasil penelitian menunjukan bahwa media sosial tidak memiliki dampak langsung pada kinerja. Namun, media sosial memiliki pengaruh yang signifikan terhadap kinerja melalui mediasi penciptaan pengetahuan dan inovasi. Efektifitas media sosial dapat meningkatkan kinerja bisnis dengan melakukan penciptaan pengetahuan dan inovasi.

Kata kunci: media sosial, penciptaan pengetahuan, inovasi, kinerja, UKM

\footnotetext{
${ }^{1}$ Corresponding author:

Email: ekocahyadi@apps.ipb.ac.id
} 


\section{INTRODUCTION}

The development of technology and communication has a role in increasing business; one of the benefits is the use of social media. Social media can easily open communication networks between producers and consumers in offering products to consumers, making it easier to do business. Weinberg and Pehlivan (2011) also said that social media acts as a moderator who conveys information to customers in the form of content or for sending individual businesses such as e-commerce. According to Alarcon et al. (2015) states, social media contributes to the practice of marketing customer relationships and conducting business in digital form. Using social media supports business performer to create knowledge and innovations which increasing performance of SMEs.

According to Lopez-Nicolas and Soto-Acosta (2010) technology of communication and information provides the orientation allows the knowledge creation process, to help sharing tacit knowledge among employees, translate tacit knowledge in the form of explicit and systematic in order to understand easily, combine explicit knowledge to organize in knowledge system and provides facility of discussion and conversation space to form explicit knowledge into tacit knowledge.

Through social media, the relationship between customer and business performer will be more close, and customers can make private communication to order products that suit their wants. Hanna et al. (2011) state that social media can be used as a suitable tool to influence potential customers nowadays and has the potential increase and transform products or create new products that including customers in it. According to Liang and Turban (2011), social media can open up opportunities for SMEs specifically to gain new knowledge and innovations, which will ultimately be able to improve performance. Innovation in business could be the eminence that affects significantly in the performance of a business. According to Zahra et al. (2000), innovation lets companies offer various products which different from competitors that can improve their financial performance. Therefore, social media is a platform or new place to make innovation that adapts to era development.
There are kinds of social media, such as Twitter, Facebook, Blog, Foursquare, and others (Puntoadi, 2011). In Indonesia, the number of social media users is already very high. Some of the social media platforms that most interest Indonesian people are Facebook, Instagram, and Whatsapp. According to Kemp (2017), the use of Facebook platforms reached 49\%, Instagram $41 \%$, and WhatsApp $39 \%$ of the total population in Indonesia.

In Indonesia, SMEs still have several obstacles, such as promoting and marketing products (Dewi et al. 2017). The probability amount of social media users are included partly SMEs in Indonesia. According to data released by Kominfo (2017) announced that only around 10.422 million SMEs of a total of 59.2 million SMEs in Indonesia used social media to sell their products. This fact means that there are $18 \%$ of the amount of SMEs that actively online selling products. This amount is certainly fewer than the amount of SMEs in Indonesia. Jabodetabek is a region that has a strong appeal because it represents five major cities in Indonesia and become the leading choice to build and develop business. This reason makes the Jabodetabek area as the central region of the most significant foreign exchange contributor to Indonesia, which reflects by the development of quite large SMEs in Jabodetabek. It can be seen in Table 1 the amount of SMEs units in Jabodetabek in 2017, which are divided based on each region.

In developed countries, the use of social media took a role in the development of the economy, especially the impact of social media can be felt directly on SMEs. Guesalaga (2016) states that the use of social media in the United States has great potential in product sales. Dutot and Bergeron (2016) state that the use of social media in the French already use commonly and produces added value for SMEs. It depends on the SMEs' ability to use in order to generate knowledge, customer loyalty, and become a strategy to improve business performance.

Table 1. Data on Jabodetabek SMEs (SMEs Units)

\begin{tabular}{lc}
\hline City & Total 2017 \\
\hline Jakarta & 3973 \\
Bogor & 326 \\
Depok & 1650 \\
Bekasi & 2086 \\
Tangerang & 431 \\
Total & 8466 \\
\hline
\end{tabular}


Looking at the positive impact of using social media on SMEs in developed countries, researchers are interested in finding out the impact of using social media specifically on the creation of knowledge, innovation, and performance in SMEs in Jabodetabek. This study aims to participate in the preparation of the literature relating to the critical role of social media in SMEs, and the specific objectives are as follows: 1) Analyze the level of social media used by SMEs in Jabodetabek in knowledge creation, innovation, and performance improvement for business; 2) Analyze the impact of social media on knowledge creation, innovation, and performance in SMEs in Jabodetabek.

\section{METHODS}

The data used in this study uses primary data. Primary data is data obtained directly by giving online questionnaires to all respondents in SMEs in Jabodetabek. Determination of the sample using the Cochran formula with a sampling error rate of 5\%, so the number of SME samples is 384 respondents, sampling based on non-random sampling with sampling techniques based on snowball sampling.

The field of SMEs chosen in this study crafts, culinary, clothing, and shoes with a minimum business cycle of one year. The selection of SMEs in the fields of crafts, food and beverage, clothing, and shoes in this study is because all four fields of SMEs are large contributors of foreign exchange in the creative economy sector. According to the Creative Economy Agency (Bekraf, 2017), these fields have contribution to GDP (Gross
Domestic Product) with percentage in the food and beverage sector of $41.69 \%$, Fashion (Clothing and Shoes) at $18.15 \%$, Craft fields at $15.70 \%$. Data processing uses the SEM method, data analysis using SmartPLS software with validity and reliability tests with 5 points Likert scale. Value 1 (Very inappropriate), value 2 (Inappropriate), value 3 (Less appropriate), value 4 (Appropriate) and value 5 (Very appropriate).

This study has four variables that produce nine hypotheses. The dependent variable in this study is performed. The measurement of performance, according to Narver and Slater (1990), is sales volume and market share. Independent variables in this study are social media and knowledge creation. Social media can measured by the use of social media platforms, social communities, and capabilities in social media (Scuotto et al. 2017). According to Nonaka and Tauechi (1995), indicators of knowledge creation are two, which are tacit knowledge and explicit knowledge. The mediating variable in this study is innovation. Innovation can measured by product innovation, process innovation, position innovation, and paradigms innovation (Tidd and Bessant, 2009).

Each indicator of variables that already obtained through questionnaires will be processed by Structural Equation Modeling (SEM) using the PLS program. The results can used as managerial implications for SMEs and the Jabodetabek government about the impact of social media on knowledge creation, innovation, and performance in SMEs in Jabodetabek. The framework of this study can seen in Figure 1.

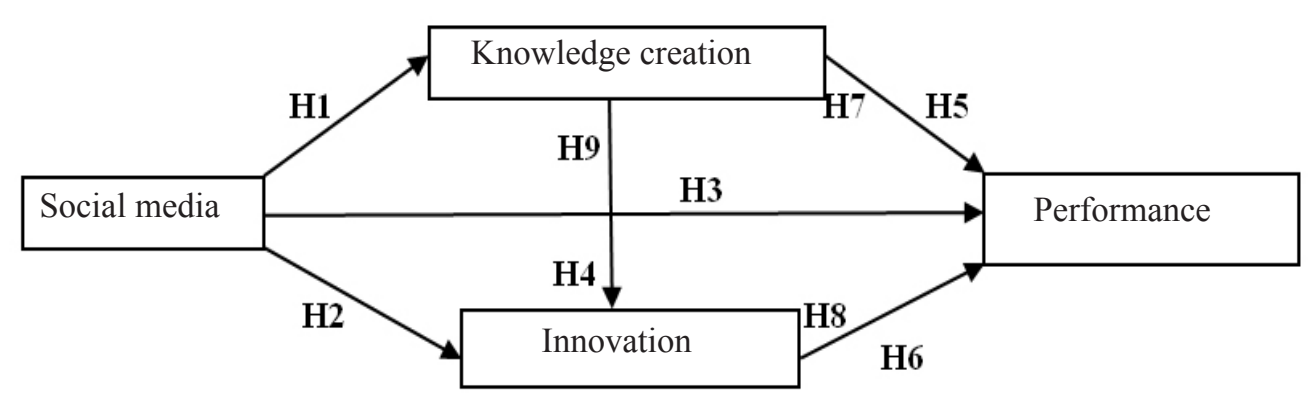

Figure 1. Research framework 


\section{RESULTS}

Analyze the level of social media used by SMEs in Jabodetabek in knowledge creation, innovation, and performance improvement for business

This research is limited to the use of social media as a tool for knowledge creation and innovation and performance in SMEs in Jabodetabek. The factors studied in this study are the use of social media as a tool that can used for sources of finding information for the creation of knowledge and innovation in SMEs obtained in previous research and direct surveys. The object of this research is a private party at UKM in Jabodetabek. Descriptive analysis in this study aims to look at the characteristics of respondents in SMEs in Jabodetabek, which processed through Ms. Excel and SPSS 20.

In this study, the respondents were SMEs that used social media in their businesses. In this study, there were about 384 SMEs in Jabodetabek as respondents, which 215 respondents collected by direct questionnaire distribution and interview meanwhile 169 respondents collected by online questionnaire distribution. Administration staff for SMEs as respondents applied only on 169 SMEs with a percentage of $44 \%$, and $56 \%$ still manage their business accounts. Table 2 below is the result of the recapitulation of the respondents' data and the results of the use of social media on Jabodetabek SMEs, which apply administration staff admin.

Based on respondent characteristics, Table 2 above shows that the use of social media on SMEs dominated by males with a percentage of $22.1 \%$ rather than ownership of SMEs that are female with a percentage of $21.9 \%$. Life characteristics of respondents in this average study age ranged from 26-35 years, with a percentage of $25.2 \%$ admin use with a standard deviation of 8.34. Educational characteristics in this study, the SMEs in Jabodetabek averaged only high school with admin use only $19.3 \%$ with a standard deviation of 5.54. This amount is less than the SMEs that do not have an admin that is equal to $33.0 \%$, with a standard deviation of 11.85 .

Table 2. Characteristics of respondents

\begin{tabular}{|c|c|c|}
\hline Characteristics of respondents & $\begin{array}{c}\text { Admin percentage (\%) / standard } \\
\text { deviation }\end{array}$ & $\begin{array}{c}\text { No admin percentage (\%) / standard } \\
\text { deviation }\end{array}$ \\
\hline \multicolumn{3}{|l|}{ Gender } \\
\hline Man & $22.1 /-$ & $23.9 /-$ \\
\hline Woman & $21.9 /-$ & $32.1 /-$ \\
\hline \multicolumn{3}{|l|}{ Age (Years) } \\
\hline 26-35 & $25.2 / 8: 34$ & $28.3 / 8.74$ \\
\hline \multicolumn{3}{|l|}{ Level of Education } \\
\hline High School & $19.3 / 5: 54$ & $33.0 / 11.85$ \\
\hline \multicolumn{3}{|l|}{ Last Experiences } \\
\hline Private employees & $31.6 / 12: 46$ & $37.6 / 14.72$ \\
\hline \multicolumn{3}{|l|}{ Type of Business } \\
\hline Food and Beverage & $14.8 / 2.50$ & $16.4 / 2.16$ \\
\hline \multicolumn{3}{|l|}{ Period of Business (Years) } \\
\hline $1-5$ & $27.3 / 3.74$ & 41.4 / 5.91 \\
\hline \multicolumn{3}{|l|}{ Turnover of SMEs Income } \\
\hline $1-20 \%$ & $23.4 / 3.32$ & $26.0 / 4: 49$ \\
\hline \multicolumn{3}{|l|}{ Social Media Usage a Day (Hours) } \\
\hline $1-8$ & $38.0 / 11.76$ & $47.9 / 15.15$ \\
\hline \multicolumn{3}{|l|}{ Social Media Used } \\
\hline Facebook, Instagram, Whatsapp & $23.5 / 8.96$ & $28.7 / 11.06$ \\
\hline
\end{tabular}


Characteristics of this type of business are the largest in this study of SMEs in the food and beverage field with the used admin at 14.8 with a standard deviation of 2:50 and did not use the admin of $16.4 \%$ with a standard deviation of 2.16. Characteristics of business long with an average of 1-5 years with the use of admin by $27.3 \%$ with a standard deviation of 3.74 and did not use the admin of $41.4 \%$ with a standard deviation of 5.91. Moreover,And an increase in the average turnover ranges from $1-20 \%$ by using the admin of 23.4 and did not use the admin of 26.0 with a standard deviation of 4.49. Characteristics of the use of social media used per day, on average, 1-8 hours with a percentage of $38.0 \%$ admin use with a standard deviation of 11.76 and did not use the admin of $47.9 \%$ with a standard deviation of 15.15. The characteristics of social media used SMEs in Jabodetabek use three social media platforms, as well as the percentage of admin use $23.5 \%$ with a standard deviation of 8.96 and not using admin at $28.7 \%$ with a standard deviation of 11.06 .

Figure 2 shows the results in the use of social media on SMEs Jabodetabek, that a variety of benefits that can done for SMEs Jabodetabek in attracting and retaining customers. Figure 2 shows that as many as 303 SMEs Jabodetabek do use social media as a place to update Latest products with a percentage of $20.70 \%$ and as many as 234 SMEs Jabodetabek utilize social media in promotion in terms of attracting and retaining their customers on social media utilization Jabodetabek
SMEs in the business world. Therefore, SMEs should be creative in terms of utilizing social media to build or improve customer relationships via social media used.

Figure 2 shows that as many as 303 SMEs Jabodetabek do use social media as a place to update latest products with a percentage of $20.70 \%$ and as many as 234 SMEs Jabodetabek utilize social media in promotion in terms of attracting and retaining their customers on social media utilization Jabodetabek SMEs in the business world. Therefore, SMEs should be creative in terms of utilizing social media to build or improve customer relationships via social media being used.

\section{Analyze the impact of social media on knowledge creation, innovation, and performance in SMEs in Jabodetabek}

\section{Outer Evaluation Model}

To analyze the impact of social media on knowledge creation, innovation, and performance, SEM-PLS employed in this study. First, we checked for validity for all variables. Validity occurs if the score obtained from two different instruments that measure the same variables are strongly correlated. An indicator is said to meet the validity if the value of the outer loading score is higher than 0.5 , AVE and communality $>0.5$. Table 3 presents the results of a test in which all the variables stated AVE valid.

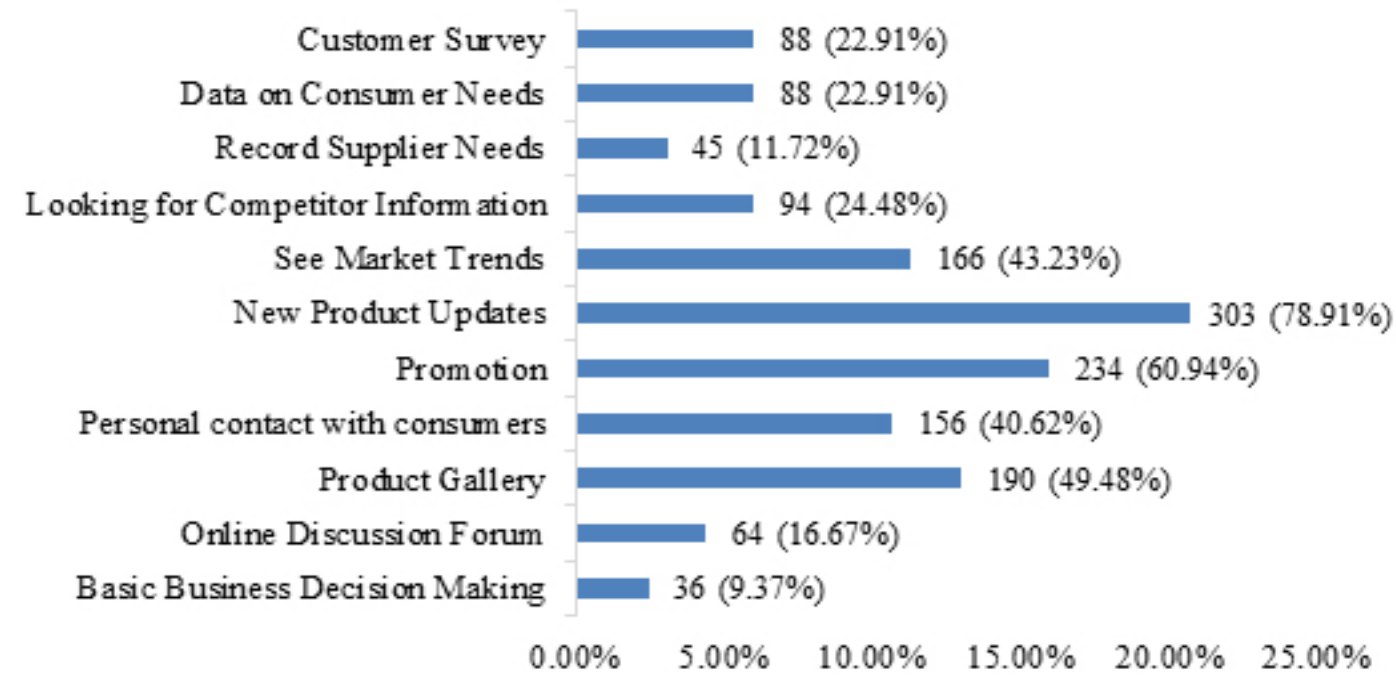

Figure 2. The use of social media in business 


\section{Inner Evaluation Model}

According to Ghozali (2008), the structural model in PLS evaluated using ${ }^{2}$ to construct an endogenous value of coefficient path (Results $\mathrm{R}^{2}$ of 0.67 either model, 0:33 model of a moderate and 0:19 models weakened) or t-values per path for test of significance between the constructs in structural model (t-statistic value $>$ t-table. At 5\% alpha, t-table value is 1.96). Therefore, if it has a value of a t-statistic of more than 1.96, it can be declared significant. In Table 4 have presented the path coefficient value of the results of the management of the structural model of bootstrapping in this study.

Based in Table 4, it can concluded that social media influences knowledge with a t-statistic value of 13.397, the value is higher than 1.96 . Social media is a place that easier every user to share experiences or discussions with fellow communities. Lopez-Nicolas and SotoAcosta (2010) states that social media capable of being a communication and information tool that provides an orientation that allows the process of knowledge creation.

Social media has an influence on innovation with a t-statistic value of 4.482 , whose value is higher than 1.96. The results of research conducted by Sawhney et al. (2005) said that social media could be a tool that facilitates the occurrence of collaborative innovation between customers and sellers in creating new products.
Social media has no effect on performance with a statistic $\mathrm{t}$-value of 1.454 , which value is less than 1.96. Research conducted by Ahmad et al. (2018) said that social media only contributes little to organizational performance caused by the adoption of social media is only a trend among businesses. This trend causes social media to become less optimal so that it does not influence the performance of SMEs.

Knowledge creation has an influence on innovation with a t-statistic value of 12.636 , whose value is higher than 1.96. The knowledge gained by SMEs translated into innovation in creating new products with a combination of customer and competitor ideas, making variation products, modifying products, using new technology. Nonaka and Takeuchi (1995) explicitly stated that knowledge is the main requirement in generating ideas and thought for innovation and competitiveness.

Knowledge creation has no effect on performance with a statistical $t$-value of 0.352 , whose value is less than 1.96. This score shows that SMEs performer in Jabodebek is limited about knowing trends, designs, market opportunities, but not implement it to increase their sales.

Innovation has an influence on performance with a statistical value of 9.606 , whose value is higher than 1.96. SMEs can innovate, such as customer approaches, community promotions, or online promotions, product quality is better than competitors, regularly product improvement. Shefer and Frenkel (2005) stated that innovation can lead to increased markets, greater production efficiency, higher productivity growth, and can increase income.

Table 3. Value AVE

\begin{tabular}{llccc}
\hline Variables & Dimension & Symbol & AVE & Note \\
\hline Social Media (X1) & Social media platforms & X1.1 & 0,518 & valid \\
& social communities & X1.2 & 0,500 & valid \\
& Social media capability & X1.3 & 0,513 & valid \\
Knowledge Creation (X2) & Tacit knowledge & X2.1 & 0,504 & valid \\
& Explicit knowledge & X2.2 & 0,508 & valid \\
Innovation (X3) & Product & X3.1 & 0,531 & valid \\
& Process & X3.2 & 0,564 & valid \\
& Position & X3.3 & 0,525 & valid \\
& Paradigm & X3.4 & 0,594 & valid \\
Performance (Y) & The sales volume & Y1 & 0,698 & valid \\
& Market share & Y2 & 0,570 & valid \\
\hline
\end{tabular}


Social media does not affect performance through mediation on the creation of knowledge. The t-statistic value is 0.352 , it is less than 1.96 . The process of knowledge creation through social media must be similar to the implemented knowledge practically so that it could become an innovation that creates a performance. Therefore, in this study, SMEs in Jabodetabek will not succeed in their performance if knowledge is not applied directly to their business through knowledge creation and innovation.

Social media influences performance through innovation mediation with a t-statistic value of 4,063, whose value is higher than 1.96. In this study, social media can be a place for a new product, innovations such as product design. Market expansion can improve the performance of SMEs. Kenly and Poston (2011) states that social media can increase profits for business people because of new product innovations, get new markets, and adopt new products from competitors and can reduce costs.

Knowledge creation influences performance through innovation mediation with a t-statistic value of 7.653 , whose value is higher than 1.96 . In this study, the media social can be a place to transact online within a group of owned communities, thus creating innovation in the digital business transaction system where every promotion, transaction, and even an increase in product sales online. Gamal (2015) states that knowledge becomes an essential resource in organizations that can improve performance by increasing awareness of resources so that it can trigger innovation.

\section{Managerial Implications}

SMEs performer in Jabodetabek expected to be able to use social media maximally, either looking for information about market trends or communicating with customers in order to create an innovation process that will produce output to improve SME performance. Social media does not influence the performance of SMEs in Jabodetabek directly. Social media utilization should not only as a trend. SMEs performer in Jabodetabek must be able to manage time and develop a division of tasks clearly for the buying and selling process through social media. SMEs performer in Jabodetabek also advised to have someone specifically to manage the use of social media. Qualification for social media administration staff who are experienced and active in running social media must be a priority choice for SMEs performer in Jabodetabek. Social media designed to have shared support features that can support business' development. For example, social media administration staff can use a hashtag $(\#)$ in captions (caption) as item-specific forms, needs, and age trends. The use of location (location) makes customers more comfortable to look for products in their surrounds.

Table 4. The path coefficient value of the results of the management of the structural model of bootstrapping

\begin{tabular}{lcccc}
\hline Path coefficient results (Direct Influence) & \multicolumn{5}{l}{} \\
\hline Variable dependent & $\begin{array}{c}\text { Original } \\
\text { Sample }(\mathrm{O})\end{array}$ & $\begin{array}{c}\text { Standard Error } \\
(\text { STERR) }\end{array}$ & $\begin{array}{c}\text { T Statistics } \\
(|\mathrm{O} / \mathrm{STERR}|)\end{array}$ & Note \\
\hline Social media $(\mathrm{X} 1) \rightarrow$ Knowledge creation $(\mathrm{X} 2)$ & 0.633 & 0.047 & 13.397 & Significant \\
Social media $(\mathrm{X} 1) \rightarrow$ Innovation $(\mathrm{X} 3)$ & 0.230 & 0.051 & 4.482 & Significant \\
Social media $(\mathrm{X} 1) \rightarrow$ Performance (Y) & 0.071 & 0.049 & 1.454 & Not Significant \\
Knowledge creation $(\mathrm{X} 2) \rightarrow$ Innovation $(\mathrm{X} 3)$ & 0.609 & 0.048 & 12.636 & Significant \\
Knowledge creation $(\mathrm{X} 2) \rightarrow$ Performance $(\mathrm{Y})$ & 0.028 & 0.079 & 0.352 & Not Significant \\
Innovation $(\mathrm{X} 3) \rightarrow$ Performance $(\mathrm{Y})$ & 0.643 & 0.067 & 9.606 & Significant \\
\hline
\end{tabular}

Note: *T-Statistics $(|\mathrm{O} / \mathrm{STERR}|)>$ T-table on alpha 5\% (>1.96) accepted; *T-Statistics $(|\mathrm{O} / \mathrm{STERR}|)<\mathrm{T}$-table on alpha 5\% $(>1.96)$ decline

\begin{tabular}{llcccc}
\hline Indirect influence test & & & & \\
\hline Variable independent & Variable mediation & Variable dependent & Indirect influence & T Statistics & Note \\
\hline Social media (X1) & Knowledge creation & Performance (Y) & 0.018 & 0.352 & $\begin{array}{c}\text { Not } \\
\text { (X2) }\end{array}$ \\
Social media (X1) & Innovation (X3) & Performance (Y) & 0.148 & 4.063 & Significant \\
Knowledge creation $(X 2)$ & Innovation (X3) & Performance (Y) & 0.392 & 7.653 & Significant \\
\hline
\end{tabular}

Note: *T-Statistics $(|\mathrm{O} / \mathrm{STERR}|)>$ T-table on alpha $5 \%(>1.96)$ accepted; *T-Statistics $(|\mathrm{O} / \mathrm{STERR}|)<\mathrm{T}$-table on alpha $5 \%(>1.96)$ decline 
The government must pay more attention to the quality of SMEs' knowledge in Jabodetabek, either in product quality or business management. The Department of Cooperatives and MSMEs in Jabodetabek expected to increase the existing knowledge. The process of training human resources owned by SMEs is much needed both in the material understanding of product design, running business operations, and especially preparing SMEs who are empowered. The government must take part in introducing products from SMEs in Jabodetabek. The organization of SMEs exhibitions should not be limited to national level, but the government must explore the international level, such as collaborating with foreign countries to promote Indonesian products.

\section{CONCLUSIONS AND RECOMMENDATIONS}

\section{Conclusions}

SMEs in Jabodetabek is familiar with media use. The results of this study show that more than $50 \%$ of SMEs in Jabodetabek use three social media platforms together in running their business. The level of social media use in SMEs, especially the daily use of social media for business, more than $80 \%$ of SMEs only use social media 1-8 hours per day. The increase of income in SMEs in Jabodetabek mostly ranges from $1-10 \%$ of the number of SMEs who were respondents in this study, even as much as $6.8 \%$ of SMEs who were respondents in this study suffered increment since using social media.

Social media does not have a direct impact on the performance of SMEs in Jabodetabek. This issue caused by there are still many social media uses that only based on trends or follow-up. However, social media has a significant influence on business performance if through knowledge creation and innovation. Through social media has an impact on knowledge creation, innovation. SMEs can increase tacit and explicit knowledge from obtained information on social media. So, it is through this process of knowledge creation and innovation that SMEs can attract customers who will improve their business performance.

\section{Recommendations}

SMEs in Jabodetabek must use social media maximally for seeking information which translated into new knowledge, and continue to be innovation and enhanced further, either in the use of social media administration staff, time of use, and use of social media for business. For further researchers could add social media platforms such as twitter and youtube for consideration and could add variables such as competitiveness might be an essential variable given the development of the digital world.

\section{REFERENCES}

Ahmad SZ, Bakar ARA, Ahmad N. 2018. Social media adoption and its impact on firm performance: the case of the UAE. Telematics and Informatics 35: 6-17. https://doi.org/10.1016/j.tele.2017.09.006.

Alarcon MC, Rialp A, Rialp J. 2015. The effect of social media adoption on exporting firms performance. Enterpreneurship in International Marketing. 25: 161-186. https://doi.org/10.1108/S1474797920140000025007.

[Bekraf] Badan Ekonomi Kreatif. 2017. Data Statistik dan Survei Ekonomi Kreatif, Kerjasama Badan Ekonomi Kreatif dan Badan Pusat Statistik. Jakarta: Bekraf.

Cochran WG. 1965. Sampling Techniques. New York: John Wiley \& Sons, Inc.

Dewi H, Maarif MS, Sunarti TC. 2017. Innovation strategy to improve the competitiveness of micro, small and medium enterprises of bandar lampung banana chips. Indonesian Journal of Business and Enterpreneurship 3(1):64-76. https://doi.org/10.17358/ijbe.3.1.64.

Dutot V, Bergeron F. 2016. From strategic orientation to social media orientation improving SMEs performance on social media. Journal of Small Business and Enterprise Development 23(4): 1165-1190. https://doi.org/10.1108/JSBED-112015-0160.

Gamal MS. 2015. Leveraging organizational performance via knowledge management systems platforms in emerging economies. VINE 45(2): 239-278. https://doi.org/10.1108/VINE06-2014-0045.

Ghozali I. 2008. Structural Equation Modeling. Semarang: Universitas Diponegoro.

Guesalaga R. 2016. The use of social media in sales: Individual and organizational antecedents, and the role of customer engagement in social media. Industrial Marketing Management 54(2016): 71-79. https://doi.org/10.1016/j. indmarman.2015.12.002.

Hanna R, Rohm A, Crittenden VL. 2011. We're 
all connected: the power of the social media ecosystem. Business Horizons 54(3): 265-273. https://doi.org/10.1016/j.bushor.2011.01.007.

Kemp S. 2017. We Are Social and Hootsuite: Digital in 2017; Southeast ASIA. a study of internet, social media, and mobile use throughout the region. https://www.slideshare.net/wearesocialsg/ digital-in-2017-southeast-asia [28 Jan 2017].

Kenly A. and Poston B. 2011. Social Media and Product Innovation Early Adopters Reaping Benefits amidst Challenge and Uncertainty. Kalipso White Paper.

[Kominfo] Kementerian Komunikasi dan Informatika Republik Indonesia. 2017. https://kominfo.go.id/ content/detail/15367/pemerintah-targetkan-8juta-umkm-go-online/0/sorotan_media. [16 Nov 2018].

Liang TP, Turban E. 2011. Introduction to the special issue: social commerce: a research framework for social commerce. International Journal of Electronic Commerce 16(2): 5-14. https://doi. org/10.2753/JEC1086-4415160201.

Lopez-Nicolas C, Soto-Acosta P. 2010. Analyzing ict adoption and use effects on knowledge creation: an empirical investigation in SMES. International Journal of Information Management 30(6): 521-528. https://doi. org/10.1016/j.ijinfomgt.2010.03.004.

Narver JC, Stanley FS. 1990. The effect of a market orientation on business profitability. Journal of Marketing 54(4): 20-35.https://doi. org/10.1177/002224299005400403.

Nonaka I. Takeuchi H. 1995. The Knowledge Creating Company: How Japanese Companies Create the Dynamics of Innovation. New York: Oxford University Press. https://doi.org/10.1016/00246301(96)81509-3.

Puntoadi D. 2011. Menciptakan Penjualan Melalui Social Media. Jakarta: PT Elex Komputindo.

Sawhney M, Verona G, Prandelli E. 2005. Collaborating to create: the internet as a platform for customer engagement in product innovation. Journal of Interactive Marketing 19(4): 4-17. https://doi. org/10.1002/dir.20046.

Scuotto V, Del GM, Carayannis EG. 2017a. The effect of social networking sites and absorptive capacity on smes' innovation performance. The Journal of Technology Transfer 42 (2): 409-424. https://doi.org/10.1007/s10961-016-9517-0.

Shefer D, Frenkel A. 2005. R \& D, firm size and innovation: an empirical analysis. Technovation 25(1): 25-32. https://doi.org/10.1016/S01664972(03)00152-4.

Tidd J, Bessan J.2009. Managing Innovation Integrating Technological, Market, and Organization Change. Ed 4th. Inggris: John Wiley \& Sons, Ltd.

Weinberg BD, Pehlivan E. 2011. Social spending: managing the social mix. Journal Of Business Horizons 54(3). 275-282. https://doi. org/10.1016/j.bushor.2011.01.008.

Zahra S, Ireland R, Hitt M. 2000. International expansion by new venture firms: international diversity, mode of market entry, technology learning, and performance?. Academic of Management Journal 43(5): 925-950. https:// doi.org/10.5465/1556420. 